\title{
THE ROLE OF FAST ATOM BOMBARDMENT MASS SPECTROSCOPY (FABMS) IN CLUSTER CHARACTERIZATION
}

\author{
Adriana F. Sotelo e Anna Maria P. Felicissimo* \\ Instituto de Química, Universidade de São Paulo, CP 26077, 05513-970 São Paulo - SP
}

Recebido em 13/2/04; aceito em 15/10/04; publicado na web em 2/2/05

\begin{abstract}
Fast atom bombardment mass spectroscopy has been used to study a large number of cationic phosphine-containing transitionmetal-gold clusters, which ranged in mass from 1000 to 4000. Many of these clusters have been previously characterized and were examined in order to test the usefulness of the FABMS technique. Results showed that FABMS is excellent in giving the correct molecular formula and when combined with NMR, IR, and microanalysis gave a reliable characterization for cationic clusters ${ }^{1}$. Recently FABMS has become one of the techniques employed as routine in cluster characterization ${ }^{2,3}$ and also is an effective tool for the structure analysis of large biomolecules ${ }^{4}$. Some results in the present work reinforce the importance of these data in the characterization of clusters in the absence of crystals with quality for X-ray analysis.
\end{abstract}

Keyword: cluster; gold; palladium.

\section{INTRODUCTION}

Although single crystal X-ray crystallography remains the only definitive technique for structural characterization of heteronuclear gold cluster compounds other techniques, and in particular FABMS, have made available valuable information especially concerning the nature of these species in solution ${ }^{3}$.

The advent of FABMS in which ion generation is achieved by bombardment of the sample by a beam of fast rare gas atoms ${ }^{5}$ resolved the limitation problem that the conventional electron impact mass spectrometry used to have in the characterization of high molecular weight cluster compounds. The FABMS spectra of these species are presented as a number of peaks with well resolved fine structures arising from the various possible isotopic combinations for a given molecular formula.

FABMS is also extremely useful in determining the molecular formula of the parent cluster ${ }^{6}$. Assignments of the clusters fragments provide additional information about cluster composition. As an example the FAB spectrum for the supra cluster $\left[\mathrm{Pt}_{2}\left(\mathrm{AuPPh}_{3}\right)_{10} \mathrm{Ag}_{13} \mathrm{Cl}_{7}\right]$ shows in the 4500 to 7000 range some masses assigned to molecular fragments ${ }^{7}$. In general the most abundant peak in this range is due to the parent cluster molecular ion. In many cases the use of this technique provides the best information about the nature of a new or novel cluster when the XRay quality crystals are impossible to obtain. Then, associated to other spectroscopic techniques as NMR, IR and with microanalysis gives a reliable characterization for compounds with high molecular weight. Many examples are given in order to emphasize the power of this technique for cluster characterization.

\section{FABMS and cationic clusters}

The synthesis of new cationic mixed gold clusters with transition metals and triphenylphosphine $\left(\mathrm{PPh}_{3}\right)$ as ligand is a field of great interest due to their potential utilization in catalysis ${ }^{8,9}$.

Research involving ligand stabilized metal clusters has increased considerably in the last two decades and great progress has been

*e-mail: ampfelic@iq.usp.br achieved in this field. These compounds have gained attention among chemists and physicists due to their fascinating geometries, unique fluxional behavior, catalytic potential and interesting chemical reactivity ${ }^{6,10,11}$.

Originally the studies of metal clusters dealt primarily with their synthesis and structure determination. More recently efforts have turned towards a systematic study of chemical reactivity and catalytic properties ${ }^{6}$.

The report on the synthesis and characterization including a single crystal X-ray crystallographic analysis of the first cluster compound containing $\mathrm{Au}-\mathrm{Pd}$ bond was published in $1989^{10}$. Since then only some new and novel clusters of this type have been synthesized and well characterized ${ }^{12}$.

The cationic cluster $\left[\left(\mathrm{PPh}_{3}\right) \mathrm{Pd}\left(\mathrm{AuPPh}_{3}\right)_{6}\right]\left(\mathrm{NO}_{3}\right)_{2}(\mathbf{1})$, a promising complex for reactivity studies was first isolated by Ito et $a l^{10}$ as a minor product of the reaction between $\left[\mathrm{Pd}\left(\mathrm{PPh}_{3}\right)_{4}\right]$ and $\mathrm{AuPPh} \mathrm{NO}_{3}$ in $\mathrm{CH}_{3} \mathrm{OH} / \mathrm{CH}_{2} \mathrm{Cl}_{2}$ using inert atmosphere. The minor product of this reaction was identified as (1) and separated from the major product $\left[\mathrm{Pd}\left(\mathrm{AuPPh}_{3}\right)_{8}\right]^{2+}$ by HPLC . The cluster was later prepared with better yield using palladium acetate as precursor ${ }^{11}$. Another faster synthesis of this cluster has been carried out with $\mathrm{Pd}\left(\mathrm{PPh}_{3}\right) \mathrm{Cl}_{2}$ and $\mathrm{AuPPh}_{3} \mathrm{NO}_{3}{ }^{13}$. The addition reaction of $\mathrm{NH}_{4} \mathrm{PF}_{6}$ salt to the cluster $\left[\left(\mathrm{PPh}_{3}\right) \mathrm{Pd}\left(\mathrm{AuPPh}_{3}\right)_{6}\right]\left(\mathrm{NO}_{3}\right)_{2}$, provided a new cluster with $\mathrm{PF}_{6}^{-}$as counterion, and the crystal and molecular structure of this compound has been reported ${ }^{12}$. The characterization was also made by ${ }^{31} \mathrm{P}\left\{{ }^{1} \mathrm{H}\right\}$ NMR, microanalysis, IR and FABMS. The FABMS data are the subject of the present article.

A new phosphine stabilized Au-Pd cluster compound $\left[(\mathrm{dmpi})_{2} \mathrm{Pd}\left(\mathrm{AuPPh}_{6}\right)_{3}\right]\left(\mathrm{NO}_{3}\right)_{2}$ was prepared by direct reaction of dmpi (2,6 dimethyl phenyl isonitrile) with the cluster (1) under nitrogen atmosphere. The structure for this cluster was obtained ${ }^{14}$ in agreement with FAB data (two isonitrile groups substituted the $\mathrm{PPh}_{3}$ group present in cluster (1)).

The addition reaction of $\mathrm{Hg}^{\mathrm{o}}$ or $\mathrm{Hg}_{2}{ }^{2+}$ to the cluster (1) was also reported ${ }^{15} .{ }^{31} \mathrm{P}\left\{{ }^{1} \mathrm{H}\right\} \mathrm{NMR}, \mathrm{IR}$, and FAB-MS data were very useful in confirming the structure of this trimetallic cluster.

Another trimetallic cluster containing $\mathrm{Au}-\mathrm{Pd}$ and $\mathrm{Sn}$, $\left[\mathrm{Pd}\left(\mathrm{AuPPh}_{3}\right)_{6}\left(\mathrm{SnCl}_{3}\right)_{2}\right]\left(\mathrm{NO}_{3}\right)_{2}$ was prepared from the reaction of (1) and $\mathrm{SnCl}_{2} \cdot 2 \mathrm{H}_{2} \mathrm{O}$ under nitrogen atmosphere. This new compound 
has been characterized by ${ }^{31} \mathrm{P}\left\{{ }^{1} \mathrm{H}\right\}$ NMR, IR, FAB-MS and TGA/ DTG $^{16}$

This paper reports the results obtained with the use of FABMS, for some Pd-Au clusters emphasizing the utility of this technique in giving the correct molecular formula when combined with NMR, IR and elemental analysis.

\section{EXPERIMENTAL PART}

\section{Physical measurements}

FABMS experiments were carried out with use of a VG Analytical, Ltd., 7070-HF high resolution double focusing mass spectrometer equipped with VG11-250 data system.

\section{Reagents}

All manipulations concerning the syntheses were carried out under a purified $\mathrm{N}_{2}$ atmosphere with use of standard Schlenk techniques unless otherwise noted. Solvents were dried and distilled prior to use. $\mathrm{NaBH}_{4}$ was purchased from Aldrich Chemical S. A.

\section{Preparation of the compounds}

1. $\left[\left(\mathrm{PPh}_{3}\right) \mathrm{Pd}\left(\mathrm{AuPPh}_{3}\right)_{6}\right]\left(\mathrm{PF}_{6}\right)_{2}$ was prepared as described in the literature. The analytical data reported below is for the $\mathrm{PF}_{6}$ derivative. ${ }^{31} \mathrm{P} \mathrm{NMR}\left(\mathrm{H}_{3} \mathrm{PO}_{4}, 20{ }^{\circ} \mathrm{C}\right.$ ): d 50.0 (doublet with ${ }^{3} \mathrm{~J}_{\mathrm{P}-\mathrm{P}}=$ $31 \mathrm{~Hz}$ ), $\delta 62.1$ (multiplet with ${ }^{1} J_{\mathrm{P}-\mathrm{F}}=712 \mathrm{~Hz}$ ). Anal. Cald. for $\mathrm{Au}_{6} \mathrm{PdP}_{9} \mathrm{C}_{126} \mathrm{H}_{105} \mathrm{~F}_{12}: \mathrm{C}, 44.3 ; \mathrm{H}, 3.08$. Found: $\mathrm{C}, 44.04 ; \mathrm{H}, 3.23$. IR $(\mathrm{KBr}): \mathrm{v}\left(\mathrm{cm}^{-1}\right)=840\left(\mathrm{PF}_{6}\right)^{12}$.

2. $\left[(\mathrm{dmpi})_{2} \mathrm{Pd}\left(\mathrm{AuPPh}_{3}\right)_{6}\right]\left(\mathrm{NO}_{3}\right)_{2}$ was prepared as described in literature. ${ }^{31} \mathrm{P}\left\{{ }^{1} \mathrm{H}\right\} \mathrm{NMR}\left(\mathrm{CD}_{2} \mathrm{Cl}_{2}, 25^{\circ} \mathrm{C}\right)$ : AuP $\delta 45.0$ (singlet), IR: n (CNR) $2093 \mathrm{~cm}^{-1}$. Conductance $\left(\mathrm{CH}_{3} \mathrm{CN}\right.$ solution): $321 \mathrm{~S}$ $\mathrm{cm}^{2} \mathrm{~mol}^{-1}(1: 2 \text { electrolyte })^{14}$.

3. $\left[\mathrm{Pd}(\mathrm{AuPPh})_{6}\left(\mathrm{HgNO}_{3}\right)\right]\left(\mathrm{NO}_{3}\right)$ was obtained from nucleophilic addition and substitution reaction between either $\mathrm{Hg}^{\circ}$ or $\mathrm{Hg}_{2}{ }^{2+}$ and cluster (1) as reported in the literature. ${ }^{31} \mathrm{P}\left\{{ }^{1} \mathrm{H}\right\} \mathrm{NMR}$
$\left(\mathrm{CDCl}_{3}, 25^{\circ} \mathrm{C}\right)$ : AuP $\delta 43.0$ (singlet) with ${ }^{199} \mathrm{Hg}$ satellites $\left({ }^{3} \mathrm{Hg}_{\mathrm{Hg}-\mathrm{P}}\right.$ $=690 \mathrm{~Hz}$ ) due to the $\mathrm{AuPPh}_{3}$ ligands bound to $\mathrm{Pd}$ atom. The quantitative determination of metals $\mathrm{Pd}$ and $\mathrm{Au}$ : calc. $1 \mathrm{Pd}: 6$ $\mathrm{Au}\left(0.92 \mathrm{Pd}: 6.32 \mathrm{Au}\right.$ ). Anal. Calc. $\mathrm{PdAu}_{6} \mathrm{P}_{6} \mathrm{C}_{108} \mathrm{H}_{90} \mathrm{HgN}_{2} \mathrm{O}_{6}, \mathrm{Pd}$ $=3.33 \%, \mathrm{Au}=37.12 \%$ (found: $\mathrm{Pd}=3.08 \%, \mathrm{Au}=39.11 \%)^{15}$.

4. $\left[\mathrm{Pd}(\mathrm{AuPPh})_{6}\left(\mathrm{SnCl}_{3}\right)_{2}\right]\left(\mathrm{NO}_{3}\right)_{2}$ was prepared from the substitution reaction $\left(\mathrm{PPh}_{3}\right.$ to $\left.\mathrm{SnCl}_{3}{ }^{-}\right)$between (1) and $\mathrm{SnCl}_{2} \cdot 2 \mathrm{H}_{2} \mathrm{O} .{ }^{31} \mathrm{P}\left\{{ }^{1} \mathrm{H}\right\}$ NMR $\left(\mathrm{CD}_{2} \mathrm{Cl}_{2}, 25^{\circ} \mathrm{C}\right)$ : AuP $\delta 49.0$ (singlet). IR (KBr): $v\left(\mathrm{~cm}^{-1}\right)$ $=1186\left(\mathrm{NO}_{3}\right) \cdot \operatorname{Raman}: \mathrm{v}\left(\mathrm{cm}^{-1}\right)=291 \cdot 6(\mathrm{SnCl}){ }^{16}$.

\section{RESULTS AND DISCUSSION}

The reaction of $\left[\left(\mathrm{PPh}_{3}\right) \mathrm{Pd}\left(\mathrm{AuPPh}_{3}\right)_{6}\right]\left(\mathrm{NO}_{3}\right)_{2}$ (1) with excess of $\mathrm{NH}_{4} \mathrm{PF}_{6}$ gave the cluster compound $\left[\left(\mathrm{PPh}_{3}\right) \mathrm{Pd}\left(\mathrm{AuPPh}_{3}\right)_{6}\right]\left(\mathrm{PF}_{6}\right)_{2}$ in $40 \%$ yield. The compound has been characterized by NMR, IR, microanalysis, and X-Ray crystal and molecular structure ${ }^{12}$.

The molecular composition of $\mathrm{PF}_{6}^{-}$derivative was also confirmed by FABMS. These results turned possible the determination of the cluster ion formula despite not related in that publication (previously not available). Positive-ion FABMS analysis (m-nitrobenzyl alcohol matrix) of this cluster gave a spectrum with well-resolved peaks. An analysis of the isotopic distribution pattern for the most abundant mass ion in 3006.4 corresponded to the ion $\left\{\left[\mathrm{Pd}\left(\mathrm{AuPPh}_{3}\right)_{6}\right]\left(\mathrm{PF}_{6}\right)\right\}^{+}$. Other results showed fragmentation at: $\mathrm{m} /$ z 3413.8 (fragment $[\mathrm{M}+2 \mathrm{X}]^{+}$, where $\mathrm{M}=\left[\mathrm{Pd}\left(\mathrm{AuPPh}_{3}\right)_{6}\left(\mathrm{PPh}_{3}\right)\right]$ and $\left.\mathrm{X}=\mathrm{PF}_{6}\right) ; 3269.0$ (fragment $[\mathrm{M}+\mathrm{X}]^{+}$); 2861.5 (fragment $[\mathrm{M}-$ $\left.\left.\mathrm{PPh}_{3}\right]^{+}\right) ; 2664.7$ (fragment $\left.\left[\mathrm{M}-\left(\mathrm{AuPPh}_{3}\right)\right]^{+}\right) ; 2547.3$ (fragment $[\mathrm{M}$ $\left.\left.-\mathrm{AuPPh}_{3}-\mathrm{PPh}_{3}+\mathrm{X}\right]^{+}\right)$.

Although the FABMS of these mixed metal-gold clusters gave accurate information on the molecular formula, it is also very important to analyze other spectroscopic and analytical data. NMR gives information on the relative number of non-equivalent phosphine ligands. IR assignment confirms the presence of $\mathrm{PF}_{6}^{-}$as counterion. A complete analysis of the fragmentation pattern suggested that the neutral compound was $\left[\left(\mathrm{PPh}_{3}\right) \mathrm{Pd}\left(\mathrm{AuPPh}_{3}\right)_{6}\right]\left(\mathrm{PF}_{6}\right)_{2}$ (Figure 1). These data can be compared with the analogous cluster

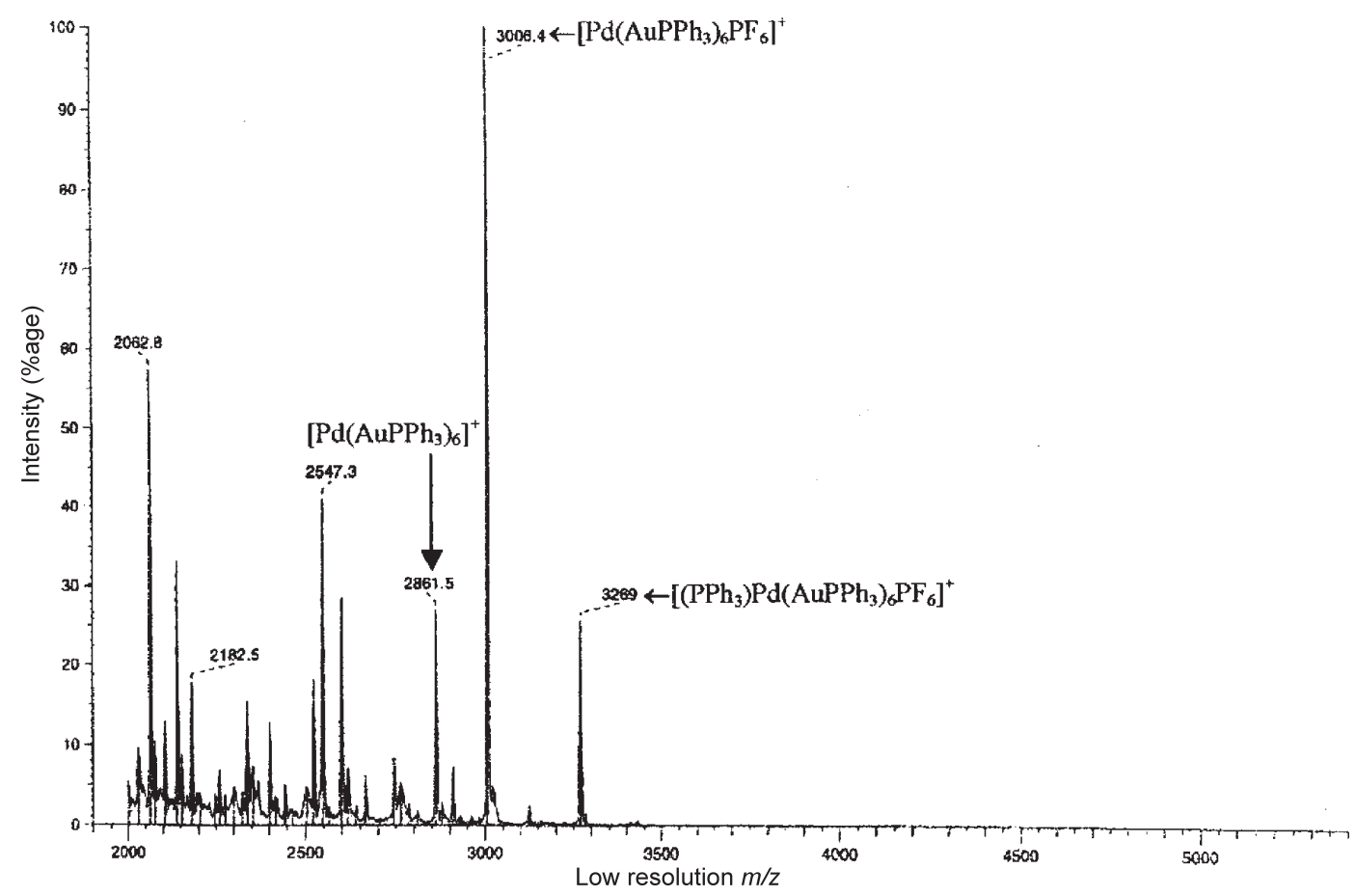

Figure 1. Positive ion FAB-MS of $\left[\left(\mathrm{PPh}_{3}\right) \mathrm{Pd}(\mathrm{AuPPh})_{6}\right]\left(\mathrm{PF}_{6}\right)_{2}$ in the $\mathrm{m} / \mathrm{z}$ range 2000-5600. The major peaks are assigned to molecular fragments as indicated 
with $\mathrm{NO}_{3}^{-}$as counterion ${ }^{11}$, and these results shows, once more, the reliability of this technique.

The FABMS analysis of the cluster $\left[(\mathrm{dmpi})_{2} \mathrm{Pd}\left(\mathrm{AuPPh}_{3}\right)_{6}\right]\left(\mathrm{NO}_{3}\right)_{2}$ gave direct evidence for the new cluster composition. The spectrum presented well-resolved peaks. The $\left(\mathrm{M}+\mathrm{NO}_{3}\right)$ ion pair was the highest mass peak and the loss of dmpi and $\mathrm{PPh}_{3}$ was noted. The results of FABMS ( $m$-nitrobenzyl alcohol matrix) where assigned as follow: $m / z 3185.3$ (fragment $\left[\mathrm{M}+\mathrm{NO}_{3}\right]^{+}$, where $\mathrm{M}=$ $\left.\left[\mathrm{Pd}\left(\mathrm{AuPPh}_{3}\right)_{6}(\mathrm{dmpi})_{2}\right]\right) ; 3056.2$ (fragment $\left[\mathrm{M}+\mathrm{NO}_{3}-\mathrm{dmpi}\right]^{+}$); 2992.9 (fragment $[\mathrm{M}-\mathrm{dmpi}]^{+}$); 2924.6 (fragment $\left[\mathrm{M}+\mathrm{NO}_{3}-2\right.$ dmpi $]^{+}$); 2924.6 (fragment $\left[\mathrm{M}+\mathrm{NO}_{3}-\mathrm{PPh}_{3}\right]^{+}$); 2861.5 (fragment [M - 2 dmpi $^{+}$); 2861.5 (fragment [M - $\left.\mathrm{PPh}_{3}\right]^{+}$); 2793.3 (fragment $\left.\left[\mathrm{M}+\mathrm{NO}_{3}-\mathrm{dmpi}-\mathrm{PPh}_{3}\right]^{+}\right) ; 2599.9$ (fragment $\left[\mathrm{M}-2 \mathrm{dmpi}-\mathrm{PPh}_{3}\right]^{+}$); 2599.9 (fragment $\left[\mathrm{M}-2 \mathrm{PPh}_{3}\right]^{+}$). Just every expected peak was present and they were all major peaks. The proposed molecular formula for this cluster was confirmed later by single crystal X-ray structure $^{14}$.

High purity crystals of the cluster $\left[\mathrm{Pd}\left(\mathrm{AuPPh}_{3}\right)_{6}\left(\mathrm{HgNO}_{3}\right)\right]\left(\mathrm{NO}_{3}\right)$ were obtained but, unfortunately, inappropriate for X-ray analysis. FABMS, in this case, was an extremely useful technique in the determination of the molecular formula. The highest mass peak was assigned as $\mathrm{MX}=\left[\mathrm{Pd}\left(\mathrm{AuPPh}_{3}\right)_{6}\left(\mathrm{HgNO}_{3}\right)\right]\left(\mathrm{NO}_{3}\right)$. Other results FABMS ( $m$-nitrobenzyl alcohol matrix) are presented: $m / z, 3182.8$ (fragment $[\mathrm{M}+\mathrm{X}]^{+}$, where $\mathrm{M}=\left[\mathrm{Pd}\left(\mathrm{AuPPh}_{3}\right)_{6}\left(\mathrm{HgNO}_{3}\right)\right]$ and $\mathrm{X}=$ $\mathrm{NO}_{3}$ ); 3120.7 (fragment $[\mathrm{M}]^{+}$); 3057.7 (fragment $[\mathrm{M}-2 \mathrm{X}]^{+}$); 2980.9 (fragment $[\mathrm{M}-\mathrm{Hg}]^{+}$).

The trimetallic cluster $\left[\mathrm{Pd}\left(\mathrm{AuPPh}_{3}\right)_{6}\left(\mathrm{SnCl}_{3}\right)_{2}\right]\left(\mathrm{NO}_{3}\right)_{2}$ was obtained in high purity state but the crystals were inappropriate for $\mathrm{X}$-ray analysis. In this case, FABMS and TGA/DTG were techniques extremely useful in the determination of the molecular formula. Positive-ion FABMS analysis of this cluster gave a spectrum with well-resolved peaks. The highest mass peak (FABMS) was assigned as $[\mathrm{M}-\mathrm{Cl}]=\left[\mathrm{Pd}\left(\mathrm{AuPPh}_{3}\right)_{6}\left(\mathrm{SnCl}_{3}\right)_{2}-\mathrm{Cl}\right]$ in $\mathrm{m} / z$ 3276.2. All the assignments are presented and results show all the usual fragmentations (Table 1). Other technique used in order to achieve the molecular formula was TGA/DTG.

Table 1. Positive ion FABMS of $\left[\mathrm{Pd}\left(\mathrm{AuPPh}_{3}\right)_{6}\left(\mathrm{SnCl}_{3}\right)\right]\left(\mathrm{NO}_{3}\right)_{2}$ cluster followed by $\mathrm{m} / z$, relative abundance (assignment) ${ }^{\mathrm{a}}, \mathrm{M}=$ $\mathrm{Pd}\left(\mathrm{AuPPh}_{3}\right)_{6}\left(\mathrm{SnCl}_{3}\right) ; \mathrm{X}=\mathrm{NO}_{3}$

\begin{tabular}{|c|c|c|c|}
\hline Species & $\begin{array}{l}\text { Calculated } \\
\text { (amu) }\end{array}$ & $\begin{array}{l}\text { Observed } \\
\quad(\mathrm{amu})\end{array}$ & $\begin{array}{c}\text { Relative } \\
\text { intensity } \\
(\%)\end{array}$ \\
\hline$[\mathrm{M}-\mathrm{Cl}]^{+}$ & 3276.6 & 3276.2 & 10 \\
\hline$\left[\mathrm{M}-\mathrm{AuPPh}_{3}-\mathrm{Cl}\right]^{+}$ & 2817.4 & 2818.3 & 40 \\
\hline$\left[\mathrm{M}-\mathrm{AuPPh}_{3}-\mathrm{SnCl}_{4}\right]^{+}$ & 2592.3 & 2592.0 & 60 \\
\hline$\left[\mathrm{M}-\left(\mathrm{AuPPh}_{3}\right)-\mathrm{SnCl}_{4}-\mathrm{PPh}_{3}\right]^{+}$ & $+\quad 2330.1$ & 2329.6 & 35 \\
\hline$\left[\mathrm{M}-2\left(\mathrm{AuPPh}_{3}\right)-\mathrm{SnCl}_{4}\right]^{+}$ & 2133.5 & 2133.4 & 100 \\
\hline$\left[\mathrm{M}-2\left(\mathrm{AuPPh}_{3}\right)-\mathrm{SnCl}_{6}\right]^{+}$ & 2062.5 & 2062.6 & 55 \\
\hline
\end{tabular}

The thermal decomposition process observed in TGA/DTG curves started at $24^{\circ} \mathrm{C}$, was pronounced at $196^{\circ} \mathrm{C}$ and finalized at $895^{\circ} \mathrm{C}$. The mass loss was of $56.3 \%$ against the theoretical result $55,5 \%$ (calculated from the mass of remaining metals). The proposed stoichiometry based on these data is $1 \mathrm{Pd}: 6 \mathrm{Au}$ : $2 \mathrm{Sn}$, that reinforces the argument of the molecular formula $\left[\mathrm{Pd}\left(\mathrm{AuPPh}_{3}\right)_{6}\left(\mathrm{SnCl}_{3}\right)_{2}\right]\left(\mathrm{NO}_{3}\right)_{2}$ for this cluster.

NMR spectrum of the cluster $\left[\mathrm{Pd}\left(\mathrm{AuPPh}_{3}\right)_{6}\left(\mathrm{SnCl}_{3}\right)_{2}\right]\left(\mathrm{NO}_{3}\right)_{2}$ showed one peak at $49 \mathrm{ppm}$ (singlet), interpreted as due to the presence of equivalent phosphorus atoms linked to the gold atoms (P-Au). The absence of other couplings in the spectrum confirms that there are no phosphorus atoms linked to palladium, as it occured with the precursor cluster $\left[\mathrm{Pd}\left(\mathrm{AuPPh}_{3}\right)_{6}\left(\mathrm{PPh}_{3}\right)\right]\left(\mathrm{NO}_{3}\right)_{2}$. The presence of $\mathrm{Sn}$ and of $\mathrm{NO}_{3}^{-}$as counterion in this compound was respectively confirmed by Raman and IR spectra.

\section{ACKNOWLEDGEMENTS}

CNPq and FAPESP are thanked for financial support. We are grateful to Professor L. H. Pignolet for the achievement of the FABMS results at the University of Minnesota.

\section{REFERENCES}

1. Boyle, P. D.; Johnson, B. J.; Alexander, B. D.; Casanuovo, J. A.; Gannon, P. R.; Johnson, S. M.; Larka, E. A.; Mueting, A. M.; Pignolet, L. H.; Inorg. Chem., 1987, 26, 1346.

2. Krogstad, D. A.; Konze, W. V.; Pignolet, L. H.; Inorg. Chem. 1996, 35, 6763, and references therein.

3. Mingos, D. M. P.; Watson, M. J.; Adv. Inorg. Chem. 1992, 39, 327, and references therein.

4. Hirayama, K.; J. Mass. Spectrom. Soc. Jpn. 2000, 48, 289.

5. Barber, M.; Bordoli, R. S.; Sedgwick, R. D.; Tyler A. N.; J. C. S. Chem. Commun. 1981, 325.

6. Pignolet, L. H.; Aubart, M. A.; Craighead, K. L.; Gould, R. A. T.; Krogstad, D. A.; Wiley, J. S.; Coord. Chem. Rev. 1995, 143, 219.

7. Kappen, T. G .M. M.; Schlebos, P P. J.; Bour, J. J.; Bosman, W. P.; Smits, J. M. M.; Beurskens, P. T.; Steggerda, J. J.; Inorg. Chem. 1994, 33, 754.

8. Ito, L. N.; Sweet, J. D.; Mueting, A. M.; Pignolet, L. H.; Shoondergang, M. F. J.; Steggerda, J. J.; Inorg. Chem. 1989, 28, 3696; Krogstad, D. A.; Felicissimo, A. M. P.; Schoondergang, M. F. J.; Pignolet, L. H.; Abstr. Pap. Am. Chem Soc. 1993, 206, 425-INOR.

9. Felicissimo, A. M. P.; Gusevskaya, E. V.; Quim. Nova 1994, 17, 381, and references cited therein.

10. Ito, L. N.; Johnson, B. J.; Mueting, A. M.; Pignolet, L. H.; Inorg. Chem. 1989, 28, 2026.

11. Ito, L. N.; Felicíssimo, A. M. P.; Pignolet, L. H.; Inorg Chem. 1991, 30, 988.

12. Sotelo, A. F.; Felicíssimo, A. M. P.; Gómez-Sal, P.; Inorg. Chim. Acta 2003, $348,63$.

13. Sotelo, A. F.; Quintilio, W.; Felicissimo, A. M. P.; Spectrosc. Lett. 1994, 27, 605 .

14. Takata, N. H.; Young Jr, V. G.; Felicissimo, A. M. P.; Inorg. Chim. Acta 2001, 325, 79.

15. Sotelo, A. F.; Felicíssimo, A. M. P.; J. Chromatogr., A 1999, 862, 29.

16. Sotelo, A. F.; PhD Thesis, University of S. Paulo, Brazil, 2004. 